\title{
SOCIAL POLICIES AND SENSITIVITIES MANAGEMENT: AN APPROACH FROM THE SOCIOLOGY OF THE BODIES/EMOTIONS
}

\author{
Adrian Scribano \\ National Scientific and Technical Research Council \\ Gino Germani Research Institute \\ Buenos Aires' University \\ $9506^{\circ}$ Uriburu, Buenos Aires, Argentina, 1114 \\ adrianscribano@gmail.com \\ Angelica De Sena \\ Gino Germani Research Institute \\ Buenos Aires' University \\ $9506^{\circ}$ Uriburu, Buenos Aires, Argentina, 1114
}

\begin{abstract}
The aim of the present paper is to show the building process of a policy of emotions in and through the social policies implemented in Argentina as of 1976. In order to achieve this aim we have resorted to qualitative secondary data reusing testimonies and a set of interviews that we were granted by women in 2010 trying to trace, in both cases, the feeling practices involved in being "beneficiaries" of some social policy. The argumentative strategy that we have chosen is the following:

a) specification of the central themes of the theoretical and methodological approach used;

b) reconstruction of the testimonies of women from 1976 and until the 2000 decade;

c) presentation of the continuity processes of feeling practices in 2010 ;

d) ending by maintaining the centrality that social policies have acquired in the development of sensitivities.

The conclusion tries to show how the development of sensitivities through social policies plays a central role in the part these policies have in the processes through which the State occludes conflict and provides warranties for systemic reproduction.
\end{abstract}

Keywords: emotions, social policies, bodies, sensitivities.

\section{Introduction}

"There comes a moment in which you cannot even buy a pair of jeans because you are asked for a pay stub. I don't have it, so I can't take the pants with me. We are talking about a pair of pants. Do you realize the way in which you fall? You fall, but you feel flattened" [1].

"Question: How does the neighborhood feel? Answer: Flattened" (woman part of a cooperative in Córdoba, 2011).

In the last forty years Argentine women have played a key role in the social, political, economic and cultural life of the country. Women fought against the dictatorship of the seventies, they had a fundamental role in the restoration of democracy in the eighties, they were pillars of resistance against neoliberalism in the nineties and they continue to occupy a relevant place in the struggles against mega-mining, segregation and daily abuses against human rights.

As a counterpoint of the foregoing, gender wage gaps persist, gender-based violence has increased, the reproduction of gender roles is still valid and the acts of injustice regarding reproductive health have not ceased.

Even though there have been changes in social structures that can be considered a step forward in obtaining access to and exercise of rights in the past four decades, the feminization of poverty, social protest and social policies is an obvious fact.

In recent years and in the context of our research on social policies and women, an expression has emerged: flattened.

According to some dictionaries, to be flattened means: "to become discouraged", "to be knocked down", "to be defeated decisively", "to be struck so as to be made to fall down." 
It is this feeling of being flattened what gives us reasons to think, once again, about the possible connections between social policies and emotions.

The aim of the present work is to show the building process of a policy of emotions in and through the social policies implemented in Argentina as of 1976. In order to achieve this aim we have resorted to qualitative secondary data reusing testimonies and a set of interviews that we were granted by women in 2010 trying to trace, in both cases, the feeling practices involved in being "beneficiaries" of some social policy. The argumentative strategy that we have chosen is the following:

a) specification of the central themes of the theoretical and methodological approach used;

b) reconstruction of the testimonies of women from 1976 and until the 2000 decade;

c) presentation of the continuity processes of feeling practices in 2010 ;

d) ending by maintaining the centrality that social policies have acquired in the development of sensitivities.

The conclusion tries to show how the development of sensitivities through social policies plays a central role in the part these policies have in the processes through which the State occludes conflict and provides warranties for systemic reproduction.

This work has been made on the basis of two parallel investigations: one referred to the search, identification and selection of women's testimonies in research projects carried out in the last four decades that reflect their situation in relation to the State and public policies; and another that reuses work carried out specifically with women in 2010.

This work emerged from a research project carried out with women who live in the geographical area of conurbano bonaerense (Greater Buenos Aires), which includes the poorest sectors of Argentina. It encircles the Autonomous City of Buenos Aires although, administratively, it is part of the Province of Buenos Aires. A total of 30 in-depth interviews were conducted, involving women of diverse ages and from different districts. Later on, 20 additional interviews conducted by other colleagues were also considered as qualitative secondary data. Our exploratory and descriptive approach aims to open a field of discussion regarding the issue of Social Policy, based on social studies on the body and emotions.

In the course of interviewing, no particular social policy was singled out. The ideas and experiences surrounding the "Social Plans" that we analyzed are part of the narrative that has emerged in the aforementioned interviews. Therefore, in this paper references are made to various programs, from housing programs to food programs to conditional cash transfer programs. However, it is important to keep in mind that the term "Plans", as it is used by our interviewees and referred to in this work, is the result of a long-term process that carries a charged meaning with regard to the relationship between the impoverished sectors and the State.

There are many approaches to an analysis of social policies in Argentina and Latin America [2-8]. The same can be said of studies focusing on the condition of impoverished women, gender perspectives, and social policies in Argentina in particular and in Latin America in general [9-15].

The volume and quality of material in the field of social studies regarding the body and emotions has increased in recent years in Latin America and worldwide. Analyses of various emotional dimensions in relation to the makeup of society can be observed from diverse perspectives [16-25].

By way of explanation of the basic starting points that guide the analysis presented here, in the next section we tie together certain elementary notions related to social policy, social plans, and the sociology of the body and emotions.

\section{Literature review. A Synthetic Approach to the Theoretical/Methodological Framework}

From the 70s to the present, the rights and public insertion of Latin American women have certainly improved at legal and institutional levels. However, another picture emerges if one looks at the processes and everyday experiences of women, even taking into account the so-called "left turn" of many Latin American governments. As Neumann pointed out:

"In doing so, this article contributes to the existing literature by not only demonstrating how the material and relational burdens of women's triple role operate within this new social policy context but also by illuminating the ways in which women's subjectivities are shaped by these kinds of community labor. The narratives and experiences of these women illustrate the seemingly paradoxical effects of the neoliberal logic of individual empowerment embedded in these programs. 
As I will show, these programs, through their selective interventions, reinforce both the gendered construction of community work as women's work and the neo-liberal ideal of self-sufficiency in women's daily lives" [26].

Another aspect can be observed in the recurrent dominance of neoliberal management mechanisms that are connected to the depoliticisation of women leaders of grassroots movements and that is not simply a result of neoliberal development practices, but it is produced through the interplay of local socio-political processes and personal biographies of activism, narratives and feeling practices with more macro-level development trends [27].

At international level, long time ago the paradox that made effective a greater presence of women in social policies and their real conditions of existence was pointed out. The feminization of policies does not mean better living standards or a break from the maternal role of women of the "Old Welfare State" [28].

An example of this can be obtained from the policy on paid and unpaid work or from the formal and informal work of women. As Chant and Pedwell wrote as regards this problem, the "strengthening" (...of programs and policies...) is not enough and is in constant danger of being inadequate.

“(...) anti-poverty programmes which emphasize employment generation will not be effective unless they concentrate on increasing low-income women's competencies and employability, while taking into account the gendered nature of the care economy as well as gendered power relations at domestic, community, local, national and international levels. Promoting women's entrepreneurship will not succeed unless women's lack of access to property rights and capital is addressed. Ensuring low-income women's access to micro-credit will bear little fruit unless appropriate training is provided to address functional illiteracy, better infrastructure and social services are developed, and assistance is provided to ease care burdens" [29].

In the complex set of practices for assistance to women: food, sexual reproduction, education, work, etc. a persistence of inequalities that reproduces the connections between State and market has been observed. For example, Misra, Moller and Budig noted as regards family policies:

"By placing women's experiences at the center of our analyses, and examining how work-family policies support women's positions as workers and/or caretakers, we develop a better understanding of how policy constellations reflect conceptions of the state, market, and family" [30].

With regard to gender poverty policies, in their measurement and assistance practices the need to repair life flows in extended periods of time can also be seen.

"Accepting that not every aspect of gendered privation is amenable to quantification and that indices will always require gender analysis to tell us about processes it is vital to start cultivating a broader and more inclusive base for longitudinal comparisons of gendered privation, and to determine whether, how, and in which particular forms, a 'feminization of poverty' is evolving" [31].

It is in this context that we witness the emergence of the need to carry out an analysis of the complex relationships between poverty, the situation of women, their living conditions and social policies during a long time period. This paper tries to illuminate, at least from a partial and qualitative gaze, women sensitivity along four decades as social policies beneficiaries.

\section{1. Public Policies, Policies and Social Programs}

In this paper, we explore an analysis of the consequences of various social policies on the lives of impoverished women, based on their own narratives, and through the lens of the sociology of the body and emotions.

The policies of the body and the emotions are inscribed and developed in determined geopolitical and geo-cultural contexts. In the current situation of the Global South we can partly characterize such context by understanding the transformation of two of the most important angles: the social regime of accumulation and the political regime. The former refers to a set of economic, social, cultural, and judicial institutions through which the process of production, distribution, and accumulation (reproduction) of material goods and values of a society is performed. The political regime can be understood as the set of governmental and non-governmental institutions and processes, carried out by social actors in whom a measure of power is vested, through which the political domination of society is exercised. 
In generic terms, "policy" as a State praxis refers to a set of actions performed in a planned manner and following deliberately designed strategies toward achieving the desired ends of those policies. And the State with its capability of coercion and the overall scope of its intervention sets itself up as the political institution par excellence, and the main executor of policies geared to producing effects that involve society at large. Thus it moves to decisively shape the public (and private) sectors of society.

When we speak of "policies" in a more narrow sense, we specifically refer to a normative and/or executive responsibility in regard to general and public order that is, in principle, exclusive to the State. Within this framework, Social Programs (SP) are understood as components of social policies in the context of regulations imposed by the social pattern of accumulation and the political pattern of government.

"The analysis of social policies unfailingly refers to the current model of accumulation, which is crucial for their assessment, and it makes it possible to understand that those policies implemented for decades turn out to be favourable formulae for the regulation of social conflicts and aspirations" [32].

"But it is also apparent that such regulation advances over the bodies, emotions and actions of each of the individuals that make up the social groups in every city, shaping and consolidating lifestyles and perceptions that organise the population's feelings" [33].

Within the previously mentioned framework, it can be considered that public policies (including social, economic and others) always correspond to a particular political project, within a political/administrative system that, as it has been mentioned, responds to the current accumulation system. Therefore, these policies necessarily reinforce the political power of a particular group at the expense of another, and at the same time, they generate processes that are internal to the State, which is intricately intertwined with the social phases related to the emergence, treatment and resolution of the "issues" that public policies try to solve. They also have an ideological nature, since they are presented to society as the only possible alternative that offers supposedly overall beneficial solutions for the nation in question.

In this context, it is possible to (at least partially) understand that social policies fulfill a key function: the mitigation of conflicts that arise amid different social classes or groups. This is the terrain where they are distinctly connected with the policies of the bodies and the emotions [32, 34-37].

There is a double-entendre in that the concrete means of allocation (flow and accumulation) of Social Programs entails a set of practices associated with the policies of the body, and also a set of ideological practices associated with the policies of emotion, aiming to diminish and/or eliminate the class conflict which at the same time these Social Programs themselves involve.

\section{2. Policies of the Bodies and the Emotions}

One of the strongest effects of social plans is that they keep their subjects within the limits of basic nutrition and energy survival requirements. This is one of the many ways in which such plans express and, at the same time, constitute a policy of and about the body [36].

Social agents experience the world through their bodies. Impressions of objects, phenomena, processes and other agents structure the perceptions that subjects accumulate and reproduce. From this point of view, a perception constitutes a natural means of organizing an agent's set of impressions. This configuration consists of a logic built by impression, perception and the result of these, which gives a sense of surplus of sensations. That is to say, it locates them on both sides of the aforementioned logic. Sensations, as results and as causes of perceptions, give place to emotions, as the effect of the process of assigning and matching between perceptions and sensations. Emotions, seen as consequences of sensations, can be seen as the completed puzzle coming together between sensations and action. So identifying, classifying and completing the connection between perceptions, sensations and emotions is vital for understanding the mechanisms of regulating sensations, used by capitalism as a contemporary means of social domination.

Now, the connections and disconnections between perceptions, sensations and emotions ordinarily operate in a "pre-reflective" state and become concrete practices amid the flow of social life, permeated by the class and status of individuals and the groups to which they belong. 
The need to distinguish and link the possible relations between sociability, experience, and social sensibilities becomes crucial at this point.

"Sociability is a way of expressing the means by which agents live and coexist interactively. Experience is a way of expressing the meaning gained while being in physical proximity with others, as a result of experiencing the dialogue between the individual body, the social body, and the subjective body, on the one hand; and the natural appropriation of bodily and social energies" [38].

For the body to be able to reproduce experience and sociability, it is necessary that "bodily energy is an object of production and consumption. Such energy can be understood as the necessary force to preserve the state of 'natural' affairs in a systemic functioning" (idem). At the same time, "the social energy shown through the social body is based on bodily energy, and refers to the allocation processes of such energy as the basis of the conditions of movement and action" (idem).

Thus, sensations are distributed according to the specific forms of bodily capital. And the body's impact on sociability and experience shows a distinction between the body of appearance, body of flesh, and body of movement. The forms of sociability and experience are intertwined and twisted as if in a moebius strip with the sensitivities that arise as a result of mechanisms of regulating sensation.

Social sensitivities are continually updating the emotional schemes that arise from the accepted and acceptable norms of sensations. They are just a little long or short of the interrelationships between sociability and experience. Sensitivities are shaped and reshaped by contingent and structural overlaps of diverse forms of connection/disconnection among various ways of producing and reproducing the policies of the bodies and the emotions. As such, the policies of the body that is to say, the strategies that a society accepts in order to respond to the social availability of individuals is a part, and not a small one, of the power structure.

From what has been put forth above, it is possible to understand that the logic of capital means that each subject is potential merchandise, and that, for them to become so, it is necessary to regulate sensations. That is to say, causing these subjects to become merchandise requires shaping the perception they have of themselves, annulling the sensation that their lives are a set of objectifications and what that implies the dispossession and plundering of their very selves. Through these conceptual vectors, the "mapping" of sensitivities that we henceforth develop can be better understood; vectors which were developed with (and by means of) previous "empirical" investigations.

\section{Discussion}

\section{1. Buenos Aires, forty years: Women, the Social Question and Public Policies}

It is evident that summarizing forty years of the set of practices that connect and disconnect women and social policies is a complex and unreachable aim. Our intention here is to show a few testimonies from women that serve as clues to rebuild the setting-up process of the current state of affairs of the aforementioned problems. The research we have carried out to this aim implied looking for testimonies in over 30 publications that account for different aspects of women's lives and their relation to the State, from reproductive health to meal plans to the current conditional cash transfers. We are aware that what we are building here is a partial view on a complex process, but we also hold that by reusing qualitative secondary data we are in better condition to bring light to our own search [39].

\section{1. 1. Testimonies from the $70 \mathrm{~s}$}

The military dictatorship from the 70 s increased the repression, impoverishment and stigmatization processes of the poor in Argentina, gradually leaving women on their own and in a context of economic deprivation.

"One morning in 1978, several individuals came to my house, threatened me that they were going to bring my house down and kill my children. My husband was afraid, so he signed some papers that stated we were leaving of our own free will. They brought a truck; we loaded what we could and saw how they demolished our brick house. They didn't give us a penny; we lost the fridge and some furniture. They left us in the countryside about $40 \mathrm{~km}$ away from the capital. There was not a single soul at the site. We built a tent with some blankets and lived that way until we could 
build a humble house with a corrugated iron roof. After that, more people started to arrive, all of them eradicated as we were. There was no water, no electric power, but my husband and others were able to set up a pump. There was no employment nearby, either. My husband came to Buenos Aires to try and take odd jobs; sometimes he got some, but he would spend all his money on food and transportation. He is a very good boy. He even went to school, but he was really miserable and started drinking. We split up because of poverty" (A. F.) [40].

During the last 40 years, at least, popular groups, and specially women, live among uncertainty, self-blaming and effort. In general, their children are the ones who break the social impotence regime since they are the only signal of future they have left.

"My job is to help men by passing them the buckets, bricks or anything else they need. To be honest, if it was for me, if I lived alone, I would not mind not having a home or living in a hotel. But I have two children that attend school and I would not like them to be wandering around, having no home, no place. I would not like them to have the same life I had, because that is not nice" (woman from Cooperativa Madre del Pueblo.).

The economic and institutional transformations of the authoritative government promoted the absence and breakdown of social and economic rights. Being illiterate and belonging to the world of No built up a set of segregations that preannounced the arrival of regulating devices of sensations related to social pain.

"Doctors would not see me at the general hospital because I did not have my ID, the whole service system had changed there, and we had to pay and whatnot. Now, they only see you through the unions. And I did not take my daughter's documents, I went to the ER and they did not see me, I went back to talk to the girls that were entering data and they told me they could not see me, that I had to go back home to get the documents. But what they did not want to do were the papers. Everyone who did not have them, came back. They had started with that system that day. They put up some signs but I cannot read; it is the same as if there was nothing..."(Ramona Silveira) [41].

\section{1. 2. Testimonies from the $80 \mathrm{~s}$}

The situation in the eighties makes up a break in continuity with neglect as relational knot with the State. This testimony of a pregnant woman who went to a public hospital shows some of its aspects. As well as the previous narrative about "appointments", in the 70 s it is possible to see a combination of disorientation and bureaucratization of "social assistance."

"All that is difficult... I know I have to go and see a lady who is from social assistance, but she keeps changing place... I have to bring some papers stating how much he earns [referring to the husband] and a little card for myself that they gave me but sometimes it doesn't work..." (Rosa, pregnant woman who goes to public hospital) [42].

Women are, again, alone. A pregnant woman who thinks about her other children who are "very young" and in another young lady (her daughter) fulfilling her role and taking charge... knowing she "cannot handle it all".

"When I am in the queue I always think about them, what they are doing... they are very young and I feel strange leaving them home alone. Isabel stays [a 14-year-old daughter], but she can't handle it all... It is a mess and I feel uneasy. I think about this and that; my head doesn't stop..." (Rosa, pregnant woman who goes to public hospital) [42, 43].

"Bearability" mechanisms have been structured throughout these 40 years: self-accountability on the backs of women is woven into the micro-history of their participations and "inclusions". Women's struggle takes place day-by-day, from health to habitat.

"Martin D. R. and Alberto R. trained us on how we should build the sewers, the septic tanks... We, the women, did it. As we learned, we realized we could not send kitchen waste into the septic tanks because we would have to empty them too often. That was the time when women struggled, when they were teaching us we said we weren't going to have the money to empty them frequently. Because of us the plumbing changed. Only bathroom waste goes into the septic tank" [44].

If there is any discontinuity between the $70 \mathrm{~s}$ and $80 \mathrm{~s}$, it has to do with the view of starvation as a public problem. From the beginning of Alfonsin's government and until the start of Menem's administration, the deepening of neglect is exemplified in food policies. Of course, there are more 
policies because there is more starvation. The repression and marginalization in the dictatorship was efficient: in the country of wheat and cows, people are hungry. Women start to be daily recipients and administrators of those policies in a process that structures animalization, racializing segregation and resignation on the long term.

"at last, I wasn't worth anything... we aren't horses that eat polenta and beans. They gave me polenta and peas, things that are useless".

Just as we found in our 2010 interview, at the end of the eighties women were witnesses of a starvation policy manipulations as obverse of social policies.

“... (PAIS) was given to some people, but they didn't enroll the whole shantytown. They wrote down only the names of those they thought they should.

A well-known strategy of popular groups such as "common cooking pots" became, with time, the center of government food policies. Soup kitchens at schools, in neighborhoods and in shantytowns multiply by hundreds: women organize, work and reproduce the sexual division of labor in the public sphere. They are survival strategies and for the improvement of living conditions that, on the other hand, build gradually a role of women as "support" for life, care and reproduction.

"The soup kitchen is so-so... Today we were speaking to some mothers because during the last two days they have been giving boiled rice with lentils, tea instead of milk, meat only once a week. They don't cook meat; today they gave them bread, a sandwich made with a hamburger that has minced meat and an apple. And for example, nowadays at home we are bad. We will see if he brings an advance today. At home they couldn't eat and they are so hungry, poor kids".

Doing politics at soup kitchens is a basic component of the long process that transversally unites impotence with resignation, even in organization and struggling contexts. Everyday life weaves the "bearability" mechanisms where sensations become body and produce the anguish that is fulfilled somewhere between anger and acceptance.

"We honestly wanted them to build that soup kitchen for the children. But nowadays not all the kids in the shantytown go because there are problems. There are always problems. There is always politics among us and our children get involved in politics. We did not want that family to hold a position again. But that family took charge of the soup kitchen for political reasons... and children eat polenta, boiled noodles and they eat the best at children's expense...".

Women start to experience the contradictions between their individual preferences and collective drive as the core of a state response to their problems. "Community shopping" entails the paradox of the structuration of a cooperative action as self-support practice in which they get used to be on their own before the market.

"I prefer to buy alone, but sister says it is better to get together the 20 of us [she refers to the other 20 families that take part in the same group, PAIS] with the money and buy the bags wholesale which it is cheaper...".

The segregation situation worsens and women constantly ask for help for their children: fear and lies (impotence constituents) are the horizon of a life that impoverishes with the passing of time.

"We have to help mainly children; we have to build soup kitchens for kids (...) because there are drugs. They use that 'poxi-ran' [adhesive brand name] which destroys them completely. Older children give it to younger children".

Women are privileged witnesses of the zoomorphication of social relationships with and among the subjects who live from assistance: the accusation of having an animal nature as limit of indignity clearly shows a set of feeling practices that weigh heavily, that overwhelm.

"There was a soup kitchen here before. It was a disaster. On the one hand, because it didn't have a table for children to eat, they ate on the floor. What were they? Pigs? That shouldn't be done".

\section{1. 3. Testimonies from the $90 \mathrm{~s}$}

The nineties were contradictory years: a deep impoverishment process together with growing movements and the creation of struggling groups. The politicization of poverty, which shows different aspects, has two significant components: road blockings and movements of the unemployed. Here starts a women's participation flow and a feminization of the protests that undoubtedly reaches its climax in the 2001 crisis. However, due to the aims of this work and the great number 
of research carried out on this topic, we will focus in showing the face of tensions between social policies and the places occupied by women during the segregation processes.

With that objective, we will start by showing situations in the 90s related to a topic we have previously developed in the 80 s: reproductive health and young women.

"One Tuesday I came here to see the gynecologist and she told me I should come back on Thursday. When I returned on Thursday, they offered me to work in a rummage sale that was held here in downtown and that day me and another girl started working. Two weeks later they offered us positions as nurse's aides and they explained us how to do the job. We took shifts and continued working like that for eight months. It was a very nice experience because we did things we had never done before. You know they do pregnancy tests? Well, once there was a twelve-year-old girl who came to have a pregnancy test and the doctor asked me to do it myself. It broke my heart when I saw it turned out positive. She had come with her school uniform and she had the face of a little girl, she had come with a younger sister, all by themselves, and the little one nudged her and they giggled... they were two little girls. I wanted to die... here I saw all sorts of things" (Teenage participants focus group) $[45,46]$.

In the nineties, the reproductive health of women, girls and teenagers implies more and more social modes of discrimination that go through the modifications that are seen in the relationship between social issues and women. The look as rule of a policy of the senses and the contradiction between innocence and pregnancy alerts us about how the nineties consolidate the "flattening" processes. Seeing a bit of everything, making body and naturalizing the making of superimposed "acceptances" is part of a policy of emotions that is deepened (and fostered) in the nineties.

On the other hand, social and family supporting networks start to have key importance in the lives of women who take charge of the private and the public. Starvation continues acting as a key link of feeling practices that become body.

"Their father sent money for the oldest son to study. All of it was divided, not spent to our heart's content; not abundant, little, but it was enough. And they got some help from their relatives because I said: 'today there is nothing, so run to your grandma's and eat everything. Don't eat the old lady so that tomorrow she can cook again.' That helped me, too"' (informal female worker) [1].

The continuity with the $70 \mathrm{~s}$ and $80 \mathrm{~s}$ can be seen around the topic of housing. Somewhere between need and shame, it is possible to observe how the contradiction between collective actions (begging for a house at Plaza de Mayo) and the place of women in the 80 s we have already stated has become natural.

"The house... Imagine if one day they kick us out or the roof collapses... I have to save money because my children or me wouldn't go to Plaza de Mayo and beg for a house or anything like that... it's embarrassing" (interview to Alda) [14].

Here, housing is a sign of how regulating devices of sensations create one of the clearest aspects of resignation: not being able to look back or forward. The no-future has become body through fear.

"I am afraid to go on... I can't look back, because of how ugly it was; and I don't want (to look) forward... all that I still have to go. It is really depressing to know that what I want is a house and I can't get it"' (interview to Iris) [5].

Women's bodies in the practice of abortion are a clear metaphor of the repression and criminalization of the protest which in the nineties takes a strong cruel turn. Crying as context of neglect and the tagging ways of every heterodox body are clear signals of how starvation, persecution and segregation are part of women's daily lives.

"They had me walking around all day long, going up and down to the fourth floor. All doctors and even nurses asked me if something had been done to me, if I had had a suction catheter inserted into my body. It's as if they were blaming me for something, you know? It bugged me so much that I spent the whole night crying afterwards...".

\section{1. 4. Testimonies from the $2000 \mathrm{~s}$}

As we can see, the nineties supported emotions policies that have been structured through a set of feeling practices that, when naturalized, turned into producers (and reproducers) of succes- 
sive and accumulative "losses". Economic politics of morals in the process of what we call "flattening" starts to deepen and naturalize.

The 2000 decade entailed a set of social policies oriented towards the regulation and evasion of conflictive processes that are progressively presented as individual rights and social security transformations. From different perspectives and state practices, a chain of interventions starts to be set up which, with the format of the classic meal plans or the conditional cash transfer programs, has women as its main beneficiaries. We cannot, and it is not our intention here, rebuild history which, due to its complexity, would move us away from our objectives. The following aims at continuing with our research about feeling practices.

Once again, soup kitchens are one of the centers of the feminization of flattening. The continuity of some narrations from preceding years is evident:

"That they cook food well and serve it on time," "that once in a while they vary the meals, change them, so that it isn't only stew," "I would mainly change the kitchen group, it isn't good," "no, you can't say anything because here you're actually begging" [47].

The social forms that naturalizing help takes has a direct impact on sense policies: taste, variety and time are "resistance" points, but also they are also points of making body what they have.

From another point of view, as Núñez states, "in the words of a female interviewee from the FTV-CTA soup kitchen in Santa Lucía: 'if I worry about their children, they should come to the meetings' (conversation with Luisa, July 17 $7^{\text {th }}, 2004$ )" [48]. The tensions between feeding, collective practices and feeling practices acquire special contradiction and complexity forms.

The complex circularity of doing something for others and "making a living out of it" acquires relevance in the trust/distrust between givers and beneficiaries; women describe a set of feeling practices that go through embarrassment and anger.

"They favor their people, feed them, everything is fine; they have them there, as in reserve. They need something bigger than that, if there is a demonstration they take them all since they are like 'oh, I gave them food'. They are there and I don't like that. For instance, it isn't my fault that a woman comes with 12 children; you know what I mean? 'Look after yourself, woman!' I would say to her... But they are always there, on that person and no one else. But there are other people who also have needs and they don't have so many children" (interview of the author to Beatriz, November $\left.19^{\text {th }}, 2003\right)$ [48].

This continuity/centrality of the food/starvation pair in the formation of feeling practices intertwines with the assistance/dependence forms of PTCI (Conditional cash transfer programs). The following are some examples of narrations from beneficiaries of the Program for Unemployed Male and Female Heads of Households (Plan Jefes y Jefas de Hogar Desocupados, PJyJHD in Spanish):

"But there are also people, a lot of people, who don't need it and are getting it, maybe it's unfair [...]. Yes, I feel a little angry when there are people who don't need it: they have a car, they go on vacation, you have to have a nerve to do something like that, but they do it anyways. I think this is all so wrong... and there are people who really need it. The other day I went to a house that was so tiny, wind came in through lots of places, it doesn't have floors and the children who live there are so small, so skinny and you can tell they are undernourished, just look at their face, their eyes are sunken... they are skinny...” (female PJyJHD beneficiary, Florencio Varela).

Women narrate the close links between needs, bio-politics and starvation policies that consolidate the idea of a political management of needs. Receiving a subsidy without having needs opens the door to "those who have the nerve" in their double condition of insensitive witnesses and "cronies"

"I didn't have much information, we didn't know... because this thing of the plans... you heard about this for example from the neighborhood's political point man who only told his friend, his brotherin-law, his neighbor, and so on. Therefore, only those people heard about the plans but we didn't. People who needed them, because I did need them a lot, because he [ex-husband] had been fired and stopped giving me money for our daughter..." (female PJyJHD beneficiary, Florencio Varela).

Limited access marked by someone who "runs" the neighborhood is another side maintained throughout these four decades; the relationship circles are still circles of acquaintances, relatives: women narrate over and over again the feeling of being shut out among the excluded. 
Programs change, conditionalities stay, but emotion management in relation to the needs is tied into a complex network of sensations that revolve around inequality.

"I worked, I started to earn good money and I thought it wasn't right [to continue receiving the Family Plan]. In fact, I have some coworkers who hold two positions and receive the plan because they are single moms. The same program. And I say 'How is it possible that information isn't cross-referenced at some point? I would be scared, I thought about it: at some point the information will be cross-referenced and this is a criminal offense against the State!" (La Matanza, former Family Program beneficiary, teacher) [46].

Conditionalities, bureaucratic traps and distances between fellows build a set of contradictory sensations like distrust, fear and anger.

"I got the plan in this way and I'm never going to stop thanking them because they were really nice to me and they are very very responsible people because the other day something awful happened to me and they went over there where they collected my salary and then went over there. Here is different, before... before I worked for five months here at Turco's and he fired me because I didn't pay two pesos, he fired me" (Interview from the author to Norma, November 19 $\left.{ }^{\text {th }}, 2003\right)$ [48].

A key aspect that appeared in previous decades and that shows up again in our 2010 interviews is the political point man, the one who "runs" the neighborhood, the one who acts as president. We do not believe this only refers to modifications in clientelism or to an institutionalization of what is not institutionalized, but to sociability and experience made body and that function as conflict state regulation reproducers.

\section{1. 5. Buenos Aires, 2010: Women, Social Programs and Social Sensitivities}

While Social Programs (SP) are accepted and understood as a necessary compensatory mechanism, the experience of interviewed women highlights their biased, discretionary and political nature. Being a beneficiary of a social program does not give an impoverished woman enough to meet her needs. A life of social exclusion, segregation and class and gender discrimination consolidates and worsens.

In mapping out at least partially these women's perceptions, visions and/or representations of social policies, we are faced with a scenario consisting of dearth, resignation, and fear, from the normalization of social welfare to the beneficiary's acceptance of their place. Alongside the energies they invest in surviving, looking after their children, siblings, grandparents, cousins and family friends, and the strategies they employ to make a living, the poor women in the conurbano view Social Programs as a natural feature of poverty, as something that is to be expected.

We have selected as examples two topics that emerge from the interviews:

1) the existence of a discretionary system of allocation in Social Programs;

2) the "unwanted consequences" of State actions.

Each of these topics becomes an issue of the policies of the body and the emotions, placing impoverished women in an increased state of heteronomy.

\section{Discretionary System of Social Programs Allocation}

If we were to denote the key elements that pass through the strategies which a society accepts as responses to the social availability of individuals that is to say, its policies of the body these would be: capacity for expression/movement; social norms of distances and proximities; and the potential for autonomy. Along these, four vectors align that together compose the negative implications of social program allocation:

1) embarrassment of speaking openly about the topic;

2) manipulation of resource allocation;

3) local hierarchical handling of said allocation;

4) informal systems of favoritism toward the beneficiaries of SPs.

\section{1. "We don't speak of such things"}

A common thread throughout the stories of the interviewed women was their perspective on Social Programs in connection with politics. From discussion of the discretionary system to the 
fear of being identified by "politicians" by means of their stories, the women who were interviewed see themselves in a position of vulnerability to "politics".

There is assimilation between social policies, political parties, and Social Programs. So much so that from the perspective of the interviewed women, everything looks like politics. It has become an issue which is better for them not to speak about.

It is natural that distrust and fear in regard to politics would result in the person asking questions (the interviewer) "positioning" the answer.

Here our interviewee notifies us that if the interviewer does not belong to a political party, then she will speak freely:

"So ... Let me ask you something, Mariana ... Do you receive any Social Program assistance? Or did you receive any when the children were younger?"

You know, not long ago I had to talk about that, I don't remember why ... That always ... It's possibly a criticism of mine ... I don't know if you work for the government ... or who do you work for?

No, no. I work at the Faculty.

The Faculty (laughs).

So you can say whatever you want...

Can I say whatever I want? Because I am inclined to expound...

(In a friendly tone) You can expound as much as you want.

Er ... about social programs, I've always thought that they're improperly allocated, because they're always handled under a political flag, a political ideology. It's okay that he's a party operative and he has all his friends along with him, they all get on a bus, they take them to vote. And they, of course, are the privileged ones. I worked once as an assistant, let's say, to a party operative for a while, and I learned lots of truths. And in fact I never wanted to ... I didn't want ... (Woman, 48 years old).

Once she feels at ease and free to talk, naturally improper allocation comes up in her narrative and she acknowledges knowing the truth regarding a process that makes or breaks one's chance of benefitting from a program. The "parallel" considerations, their obligatory nature and their methods are cornerstones of the prevalent distrust in politics.

This example, which we present as having a paradigmatic character, is an indicator of how the implementation of Social Programs brings about the development of specific emotions and functions that pull toward the recipients' loss of autonomy.

\section{2. Manipulation}

Another aspect that is seen in the framework built by the narratives that we present here is a certainty that the allocation of social program benefits is subject to manipulation.

The text reproduced below shows two components of everyday sensitivities that can be connected with the living conditions of the poor in Argentina: the presence of TV in their lives, and the analogy between TV format and policy execution.

The narrator compares the judging panel in Tinelli's TV show with the allocation of SPs and the political manipulation that surrounds it. The policy of SPs is seen as something that has been "arranged" and that is distributed among relatives, friends, and/or political followers.

Right, well, okay ... And is there anything that you think should change in regard to these programs?

Yes, it's like ... Have you seen Tinelli's show? The jury... how everything is manipulated?

Yes.

Well, that's the way it is.

That way.

Right, you see, everything's manipulated. Of course, they put their relatives there, they help each other. It's obvious that the relatives of the people involved get the assistance first, and afterwards the rest get theirs...

Yes. 
And that's not the way it should be. I think that they have to give it to the people who really need it, you see (Woman, 16 years old).

What you get through a social program is a "staging" of what is already developed and planned, in the same way as it happens on TV. Someone has already written the script for these impoverished women's lives.

Being the beneficiary of a program is interpreted as dancing for the fulfillment of a dream before a jury that you know will not be unbiased, nor judge according to the level of need but according to political and family ties. The mechanisms for selection and allocation of SPs are lived out as a staged play.

The disconnection between need and supply within the programs, as felt by the interviewee, opens the door to think about a redefinition of sociability in regard to the programs to find a way through which what is left unscathed will be the very need to be part of them.

\section{3. President of the Neighborhood}

The discretional roles have everyday names, given meaning by the practices that reveal the operational mode of a (complex) plot of reinterpretation of program management systems. Barely perceptible and accepted bodily positioning determines the proximity or distance among the subjects.

On the surface of the interviewee's story lines, you can see, strongly, the mutation of collective and group hierarchies as well as the consolidation of "territorial bureaucracies." The next story is an example of discretionary judgment made flesh, forming a central part of indubitable sensitivity:

And that program was also assigned by my sister. And they're getting 150.

And does your husband take part in a program?

No, my husband's just working.

Working ... and you told me that you're expecting something for him with an association.

Yes, I hope he gets it.

And does your sister work for an organization?

Yes, she's the president of the neighborhood.

Your neighborhood?

Yes, she's the president of the neighborhood and the president of the soup kitchen.

Where you work on Thursdays...

Right. She is the one who makes or breaks. For example, if I don't do my duties of ... for example, if you are pregnant and you tell me 'I'm 2 months pregnant, what do I have to do?' I give you a paper that you have to take to the obstetrician, the woman in the maternity ward that sees you, and she has to fill it in for you. And then you bring it back to me, and I have to take it to the program called "Vida." Then you can get milk. Then, I think 6 months after that, they give you a card to buy groceries (Woman, 51 years old).

In this account, as in other passages analyzed in this work, it is evident how the "territorial management" of the "program management" works: through development of informal discretionary powers and structures. The statement "She is the one who makes or breaks..." clearly shows that what happens, or does not, is at the behest of an individual. To put it in terms of a social theory formula: the definitions of power in classic sociology (Weber) and in contemporary sociology (Giddens) are put into action, showing themselves present in the management of social programs.

It is a power rooted in structure, the power of the sensitivities that develop day by day, unfolding the consequences of "applications" to social programs in a setting of social segregation and exclusion.

\section{4. The Acomodados: Social Welfare Cronyism}

The lives of the impoverished women whose interviews we are analyzing comprise of tensions between experiential and social interactions. They are troubled by the feeling that there are privileges for some at the expense of many. The narrative that follows is an example of how women perceive the giving of privileges as part of the structure and implementation of Social Programs. 
Do you believe that it should be carried out in another way? ... Or how do you see that? ... Or, would you prefer that there were no programs? Do you think they should be different?

Sometimes I think I would prefer that there were no programs, because they gather bums together. Like those for children, those for people who have more than three children ... Anyway, there are people who need it, but others don't, they prefer being on the streets than actually working.

You see that, let's say, people that don't need them are receiving them. And maybe you think that should change, if the programs continue.

Yes, it should be stricter, shouldn't it? They should know clearly who is receiving benefits and who isn't.

Isn't there some kind of control?

No, because it seems it's all favoritism... Actually, it is all favoritism (laughs). It's not that it seems like it is, it is.

Yes.

That's why I'm telling you all this. The 'acomodados' are the first ones, and then, the ones who need it don't get it (Woman, 39 years old).

There are some who do not need the assistance but get it anyways because of favoritism or "social welfare cronyism." These are called the "acomodados" a Spanish word that means getting something due to string-pulling, and also being comfortable, being at ease. This means many are living according to pretenses, as actors whose scripts are already written and who repeat the same lines every day, according to the program. The program is an iron cage: it is planned that they should remain on the sidewalks. The Weberian bureaucracy is replaced by the very presence of its rational recipient: mere planning. Dispassion is a condition that gives the program the chance to succeed.

A world of acomodados (those at ease due to favoritism) is lived out in the sociability and experience of SPs. Sensitivities are built into the perception of recipients. This skein of subordinations is added to other vectors discussed in this work, which are linked to SP territorialism: there exist "masters" who deal out program assistance according to territories. The immutability of women's needs is part of the "hijacking" they experience in their lives. There is an agreement with social program allocators not to rock the boat.

The political schemes generating fear "of that of which we do not speak", the discretionary powers that bring about a certainty of manipulation in program management, the presence of commonplace parallel territorial hierarchies, and the strong sense of development of a world of favoritism are how we could describe the central aspects of the sensitivity of women who are beneficiaries of Social Programs in Greater Buenos Aires (GBA).

However, one of the most important vectors of the allocation methods of Social Programs is seen in the form of other "consequences" of social welfare. It generates structures and ideological practices which are not explicitly expected.

\section{5. Learning to buy}

Key points regarding social practices emerge from the accounts of interviewed women. Outlined by them are diagrams of a set of consequences that might be classified as the least ambiguous in regard to the effectiveness of the aims of Social Programs. Women's experiences within SPs become input leading toward new sociabilities; new routines of receiving assistance, reconstructing social sensitivities.

Conditional cash transfers link "beneficiaries" to a system of banking purchases, or at least they facilitate their introduction to it. One learns to "be a poor person with a card." The global market is present within the welfare assistance of SPs, and the banking system also benefits from it.

Accessibility of banking services for the poor extends and consolidates their integration with society through consumerism.

How long have you...?

I've been receiving it with my card for four years, and I received it before, without the card. They brought the groceries to the retirement center. 
Oh, so you had to fetch the groceries. And which of the two methods is preferable from your point of view?

Both are good. The thing is that with the card it was ... Because the first month with the card I would hardly buy anything, as they had been giving us so many groceries. ... When the cards came, they didn't give us many things. And then, when you went shopping with the card, you would hardly buy anything. And now that I'm used to it, I buy quite a lot (Woman, 33 years old).

This story exemplifies many others. They get used to buying and calculating to increase their means. The poor receive the practical lesson of the reality of mercantile exchange. SPs produce a "modern" citizen without modernity.

Amid segregationist urban schemes, racialized social relationships, and extremely polluted living conditions, impoverished women in GBA affirm their subordination by joining the banking/financial circuit.

\section{6. Favelization}

Many of the interviewed women's accounts highlight the resurgence of the shantytown reality. According to the following account, many people arrived at these places as children and have now turned into lazy bums and drug addicts. The die is cast and cannot be changed. Fate cannot be defeated by help, Social Programs or houses: the shantytown is back.

One of the effects of the allocation methods of Social Programs is the resurgence of the ghastly structure of the shantytown as a performative place for misfortune.

Er, I went to ... well, my cousin lives in those houses, but all the people who live there come from shantytowns.

Uh-huh.

You know that there are people they've taken from the shantytowns.

Right.

The houses were beautiful, and now I went to one of them, recently ... it's horrible. They've turned it into a shantytown ... I mean, compared to what they were when they got them, they were all painted, very beautiful. Everything's ... You see, when ... I don't discriminate against them 'cause there's a shantytown over here and all that, but people are not just like that, and it's as if ... you see, if you have good things, look after 'em... if you were given a house... Well, some have paid all the installments... People who, you know... there are good people and bad people, drug addicts, thieves, good people, everything and everywhere, so... they gave 'em those little houses... three years ago they were given those little houses and they're already ruined, and those people were from the shantytown near my house...

The same happened in Moreno (locality of the Province of Buenos Aires)... Moreno was also very beautiful, beautiful buildings... buildings like those ones... you get in and you don't know if you'll get out, but when they went to live there they were all babies, all little children, and you know, they began to get together... to keep bad company...

And why do you think that...?

I think people grow, children grow and they've taken their... their own path, and also, you see, drugs are everywhere (Woman, 26 years old).

That is the result of "keeping bad company", always the same; social welfare caused the inexorable fulfillment of the shantytowns residents' fate.

The shantytown is here to stay. In terms of social relations it is one of the "unwanted consequences" of social policy. What is received and is not put to use reinforces the stereotype of the shantytown as a metaphor of impropriety.

\section{7. Private is Better}

With regard to unintended consequences as a result of state actions, a strong theme in the narratives of those interviewed was the consecration of the "private" as endowed with a "social magic", making it drastically different from the "public."

State assistance is seen as lacking, as something incomplete. State assistance is felt to be insufficient, categorized as "not enough." 
The lacking experience is a vital "cog in the machine" and provides a sensibility that reinforces the similarities and differences between public and private.

And how are things in the schools? What do you think?

Well, at school it's like the children confront, they confront. I mean, they don't all go to the same school because... because the children from here can't move there, to, you know the 102? Children from here can't go there. The ones that go to the 63 [in an angry tone], well, things that happen... I don't like the schools here, I don't like them, you know, because they smoke in the toilets, they take drugs... and I don't want my daughter to be in that environment... In private schools those things don't happen... There are no such things... because they're girls and... I care about them so much.... And I don't like these schools. I would prefer to pay and send them there, I would pay for it with my allotment. For the time being I'm receiving it (laughs)... but yes, anyway, I've always liked it.

Where's that school?

You have to go past the ... Did you cross a railroad track?

Yes.

Well, two blocks from there.

Is that in ... another neighborhood?

It's in the Morón area (Woman, 26 years old).

A few blocks further away, but better, the private school keeps dangers at a distance and becomes the beneficiary's beneficiary. With Social Programs, the mechanisms of privatization are activated, the "market" benefits, and SP recipients turn into consumers.

They become market participants and therefore are subject to market "laws."

\section{8. The Logic of Exchange}

The Social Program is transformed into merchandise. One of the sensitivities associated with the programs is their constant and repeated pattern of changing focus.

What is received can be sold or exchanged on the market. To receive a little house does not mean that they are going to live there, but it implies the endowment of a resource for the market... buying and selling is done in a framework of the insecurity and precariousness that is a part of welfare.

And how did he enter in the housing program?

A girl that was my mum's friend, one that went to the church ... she had a house, and she got this other one and she didn't want to live there because of the insecurity, and her girls couldn't go to school from there, and that sort of thing. So she offered it... as he needed a house, a place to live... She asked him if he wanted to buy it, and he accepted. And also because he was about to get married, he got married recently, so, that's why (Woman, 16 years old).

SPs create consumers and "speculators" who are poor, but who are included in the market and its "laws of rationality." There is resource allocation for informal real-estate speculation.

\section{9. Paying Debts}

The financial assistance given via Social Programs empowers the formal and informal loan systems that have been structured among the poor who hold conditional cash transfers. The program is aid, nothing more.

State aid is used for paying loans (and dries up). It is consumption-oriented. "It helps you buy things for yourself." The aim of the program is clear: to expand internal consumption, to make sectors of the populace get into debt by helping them to buy.

A) And in the future, what would you like to do? Would you like to work and be part of the program? Or would you prefer not to? Maybe you'd rather live on your salary?

Yes, I would go for the program, because it helps you out, mostly. If you have a lot of bills, it helps you buy things for yourself. That way. I see my sisters; they're always buying things (Woman, 16 years old).

B) No, for me it's useful, because I'm investing in something for my future. But for people in general... I'm not sure it's useful for them. It gives them a hand but it isn't a lot of money that can help them much, because the situation in which they live isn't very good. And that money they 
get isn't enough to get everything. I mean, sometimes it's useful to pay some debts, but besides the program, they have to be doing some other work, because it isn't going to be enough, like if they have many children, if things are expensive or something... it isn't enough (Woman, 24 years old).

All or almost all Social Program assistance is used to pay already contracted debts, since people are not given enough money to afford the cost of living. SPs do not provide enough, so they recreate debtors. People borrow to pay their debts, the welfare program starts, and then the cycle begins again.

In the preceding context it is not difficult to understand that the combination of unintended consequences of state action has a major impact on the sensitivity of impoverished women in GBA.

These women's stories show how they are experienced as buyers, consumers and debit cards users, paying their debts, trying to overcome lack, always living in the shadow of the shantytown ghost.

All these practices increase their dependence and subordination, at least in the way they see it.

\section{In Conclusion: Flattened}

The life of an impoverished woman who is head of a household and caretaker of children and adult family members in the Buenos Aires conurbano can be characterized by a way of feeling that we could call "flattened."

After forty years of complex building processes, there is a sensation that has efficiently helped in the setting up of a policy of emotions. Social policies have been the means through which the spreading and effectiveness of regulating devices of sensations have reproduced the State regulation system.

Assisted poverty can be likened to a steamroller that rolls over all subjectivity.

Women and their families live from program to program, with the precarious hope that discretionary powers will continue providing them enough subsistence to survive.

In the sectors studied for this work, poverty is lived in installments, in programs where the relationship between need and desire is bought and paid monthly.

Discretionary allocation and "unwanted State actions" together form social sensitivities in which the policies of emotions play a central role in avoiding conflict and in structuring social tolerance mechanisms.

Three outstanding concepts emerge from the narratives of the interviewed women which can serve as guides toward rethinking the links between social policies and emotional policies:

a) To these women, any state action with a territorial scope takes on the character of a "program," and the process of interpreting politicians runs deep, even clouding the senses;

b) A recurring sensation, built by the tension between giving and receiving, deepens their dependent nature and their heteronomous relationship with state actions;

c) The expectations and experiences that have been embodied in the lives of impoverished women in GBA due to social policies are always associated with the territorial anchoring of these programs.

This suggests the need to rethink the idea of clientelism.

Finally, the "flattening" that is experienced, as expressed by the interviewed women, reinforces and propagates policies of the bodies and emotions that emphasize the gender inequalities they suffer on a daily basis, neutralizing their possibilities for autonomy and the enjoyment of their rights.

\section{References}

[1] Belvedere, C., Carpio, J., Kessler, G., Novacovasky, I. (2000). Trayectorias laborales en tiempo de crisis. Desocupacion e informalidad laboral en ex asalariados provenientes del sector formal. En Carpio, Klein y Novacovsky (comp) Informalidad y exclusion social. Mexico: Fondo de Cultura Economica, SIEMPRO, 319-329.

[2] Danani, C. (1996). Algunas precisiones sobre la politica social como campo de estudio y la nocion de poblacion-objeto. Politicas Sociales contribucion al debate teorico metodologico. Buenos Aires: CEA/UBA, 21-38.

[3] Hintze, S. (1996). Politicas Sociales. Contribucion al debate teorico-metodologico. Buenos Aires: CEA-CBC. 
[4] Grassi, E. (2003). Politica y problemas sociales en la sociedad neoliberal. La otra decada infame. Buenos Aires: Espacio Editorial.

[5] Geldstein, R. (1994). Los roles de genero en la crisis. Mujeres como principal sosten economico del hogar. Buenos Aires: Cuadernos del CENEP, 50.

[6] Grassi, E. (2008). Los olvidos de la politica social: reflexiones acerca de la nocion y los objetivos de la inclusion social. Estudios sobre pobreza en Argentina. Aproximaciones teorico metodologicas. Argentina: Universitaria de Villa Maria.

[7] Lo Vuolo, R., Barbeito, A. (1993). La nueva oscuridad de la politica social. Del Estado populista al neoconservador. Buenos Aires: Mino y Davila.

[8] Seiffer, T., Villanova, N. (2016). Razon y revolucion, 55. ¿Que son las politicas sociales? Available at: http://www.razonyrevolucion.org/ryr/index.php?option=com_content\&view=article\&id=1107:ique-son-las-politicas-sociales-\&catid=104:trabajo-y-explotacion\&Itemid=99

[9] Faur, E., Campos, L., Pautassi, L., Zimerman, S. (2009). Rights questioned. Limitations of poverty-reduction policies in Argentina. International Social Science Journal, 60 (197-198), 353-370. doi: 10.1111/j.1468-2451.2010.01726.x

[10] Molyneux, M. (2008). Conditional Cash Transfers: A "Pathway to Women's Empowerment"? Sussex: IDS. Available at: http://www.gsdrc.org/document-library/conditional-cash-transfers-a-pathway-to-womens-empowerment/

[11] Molyneux, M. (2007). Change and Continuity in Social Policy in Latin America: Mothers at the Service of the State? Programme on Gender and Development, Paper No. 1. Geneva: UNRISD, 60. Available at: http://www.unrisd.org/80256B3C005BCCF9/(httpAuxPages)/BF80E0A84BE41896C12573240033C541/ \$file/Molyneux-paper.pdf

[12] Pautassi, L., Arcidiacono, P., Royo, L. (2010). "Idas y vueltas en las politicas sociales: el protagonismo de la pobreza en la agenda politica" en Derechos Humanos en Argentina. Informe 2010. Buenos Aires: Siglo XXI, 223-262.

[13] Tabbush, C. (2010). Latin American Women's Protection after Adjustment: A Feminist Critique of Conditional Cash Transfers in Chile and Argentina. Oxford Development Studies, 38 (4), 437-459. doi: 10.1080/13600818.2010.525327

[14] Tabbush, C.; Razavi, S. (Ed.) (2009). Gender, citizenship and new approaches to poverty relief: the case of Argentine CCT strategies, in: The Gendered Impacts of Liberalization: Towards Embedded Liberalism? London-New York: Routledge. UNRISD Series in Gender and Development.

[15] Tabbush, C. (2009). The possibilities for and constraints on agency: situating women's public and hidden voices in Greater Buenos Aires. Journal of International Development, 21 (6), 868-882. doi: 10.1002/ jid. 1624

[16] Retana-Franco, B. E., Sanchez-Aragon, R. (2010). Rastreando en el pasado... formas de regular la felicidad, la tristeza, el amor, el enojo y el miedo. Universitas Psychologica, 9 (1), 179-197.

[17] Scheff, T. J. (2011). Social-emotional world: Mapping a continent. Current Sociology, 59 (3), 347-361. doi: 10.1177/0011392111400787 ba, 247.

[18] Luna, R., Scribano, A. (2007). Contigo Aprendi... Estudios Sociales de las Emociones. Cordo-

[19] Scribano, A., Figari, C. (2009). Cuerpo(s), Subjetividad(es) y Conflicto(s) Hacia una sociologia de los cuerpos y las emociones desde Latinoamerica. CLACSO-CICCUS.

[20] Scribano, A., Lisdero, P. (2010). Sensibilidades en juego: miradas múltiples desde los estudios sociales de los cuerpos y las emociones. Cordoba: Unidad Ejecutora Universidad Nacional de Cordoba, 257.

[21] Smith, H., Schneider, A. (2009). Critiquing Models of Emotions. Sociological Methods \& Research, 37 (4), 560-589. doi: 10.1177/0049124109335790

[22] Le Breton, D. (2002). Antropologia del cuerpo y modernidad. Buenos Aires: Nueva Vision, 256.

[23] Le Breton, D. (2002). La sociologia del cuerpo. Buenos Aires: Nueva Vision, 112.

[24] Scribano, A.; Sarmiento, J. (Ed.) (2007). La Sociedad hecha callo: conflictividad, dolor social y regulacion de las sensaciones. En Sccribano (Comp.). Mapeando Interiores. Cuerpo, Conflicto y Sensaciones. Cordoba: Universidad Nacional de Cordoba, 118-142.

[25] Scribano, A.; Sarmiento, J. (Ed.) (2007). Policromia Corporal. Cuerpos, Grafias y Sociedad. Coleccion Accion Social. Cordoba: Universidad Nacional de Cordoba, 310.

[26] Neumann, P. J. (2013). The Gendered Burden of Development in Nicaragua. Gender \& Society, 27 (6), 799-820. doi: 10.1177/0891243213499447 
[27] Jenkins, K. (2011). Depoliticisation and the changing trajectories of grassroots women's leadership in Peru: From empowerment to service delivery? Journal of Latin American Studies, 43 (2), 299-326. doi: $10.1017 / \mathrm{s} 0022216 \times 11000046$

[28] Misra, J. (1998). Mothers or workers? Gender \& Society, 12 (4), 376-399. doi: 10.1177/ 089124398012004002

[29] Chant, S., Pedwell, C. (2008). Las mujeres, el genero y la economia informal: evaluacion de los estudios de la OIT y orientaciones sobre el trabajo futuro. Oficina Internacional del Trabajo. Ginebra: OIT, 60.

[30] Misra, J., Moller, S., Budig, M. J. (2007). Work-Family Policies and Poverty for Partnered and Single Women in Europe and North America. Gender \& Society, 21 (6), 804-827. doi: 10.1177/0891243207308445

[31] Chant, S. (2006). Re-thinking the "Feminization of Poverty" in Relation to Aggregate Gender Indices. Journal of Human Development, 7 (2), 201-220. Available at: http://eprints.lse.ac.uk/2869/1/ Re-thinking_the_feminisation_of_poverty_(LSERO).pdf doi: 10.1080/14649880600768538

[32] Halperin Weisburd, L. et. al. (2008). Politicas sociales en la Argentina. Entre la ciudadania plena y el asistencialismo focalizado en la contencion del pauperismo. Buenos Aires: Cuadernos del CEPED, 10.

[33] Halperin Weisburd, L. et. al. (2011). Problemas de genero en la Argentina del siglo XXI: feminizacion de la pobreza e inequidad del mercado laboral. Buenos Aires: Cuadernos del CEPED, 11, 260.

[34] De Sena, A. (2009). Cuestiones de Genero, mercado laboral y politicas sociales en America Latina. El caso argentino. Co-autora. Documento de Trabajo 13. Buenos Aires: CEPED, 90.

[35] De Sena, A. (2010). Micro-empresas, microemprendimientos, emprendimientos productivos ¿De quienes hablamos? Revista Politica e Trabalho. Revista de Ciencias Sociais, 32, 75-92.

[36] Scribano, A., De Sena, A., Cena, R. B. (2015). Social policies and emotions in Latin America: A theoretical approach to their analysis. Corvinus Journal of Sociology and Social Policy, 6 (2), 3-19. doi: $10.14267 /$ cjssp.2015.02.01

[37] Turner, B. (1989). El cuerpo y la sociedad. Exploraciones en teoria social. Fondo de Cultura Economica, Mexico, 323.

[38] Scribano, A., Boito, E. (2010). El purgatorio que no fue. Acciones Profanas entre la esperanza y la soportabilidad. Buenos Aires: CICCUS, 283.

[39] Scribano, A., Sena, A. de. (2009). Las segundas partes sí pueden ser mejores: algunas reflexiones sobre el uso de datos secundarios en la investigación cualitativa. Sociologias, 22, 100-118. doi: 10.1590/ s1517-45222009000200006

[40] Hermitte, E., Boivin, M. (1985). Erradicacion de "villas miseria" y las respuestas organizativas de sus pobladores" en Bartolome, L., Relocalizados: Antropologia Social de las poblaciones desplazadas. Buenos Aires Ediciones del IDES, 3.

[41] Llovet, J. (1984). Servicio de salud y sectores populares. Los anos del Proceso. Buenos Aires: Estudios del CEDES.

[42] Ramos, S. (1984). Maternidad en Buenos Aires: la experiencia popular. Buenos Aires: Cuadernos del CEDES

[43] Ramos, S., Viladrich, A. (1993). Abortos hospitalizados. Entrada y salida de emergencia. Documento CEDES. Serie Salud y Sociedad, 88.

[44] Alvarez, H. (2006). Mejoramiento habitacional y desarrollo de capacidades en un barrio del conurbano bonaerense. Buenos Aires: IDES. Estudio de caso: el Centro de Promocion del Joven CUADERNOS DE CLASPO-Argentina, 11.

[45] Zamberlin, N. (2006). Las organizaciones de la sociedad civil en el campo de la salud sexual y reproductiva. Buenos Aires: IDES. Estudio de caso: el Centro de Promocion del Joven CUADERNOS DE CLASPO-Argentina, 10.

[46] Zibecchi, C. (2008). Dinamica asistencial, participacion social y clientelismo politico: un analisis centrado en las experiencias de las mujeres beneficiarias de programas de transferencia de ingresos. Available at: http://www.derecho.uba.ar/investigacion/investigadores/publicaciones/zibecchi-dinamica_asistencial_participacion_social_y_clientelismo_politico.pdf

[47] Vaccarisi, M. (2004). Asistencia Social y politicas alimentarias: tension entre legitimacion y control social en Orietta Favaro (comp.) Sujetos sociales y politicas. Historia reciente de la Norpatagonia Argentina Capitulo 6. CLACSO Available at: http://bibliotecavirtual.clacso.org.ar/ar/libros/argentina/cehepyc/ cap6.pdf

[48] Nunez, P. (2006). (Des) igualdad, necesidades y legitimidad. Un acercamiento a los criterios de justicia en sectores populares. Buenos Aires: IDES. CUADERNOS DE CLASPO-Argentina, 7. 